\title{
Influence of Reservoir Infill on Coastal Deep Water Hypoxia
}

Lewis C. Linker

Richard A. Batiuk

Carl F. Cerco

Gary W. Shenk

Richard Tian

See next page for additional authors

Follow this and additional works at: https://scholarworks.wm.edu/vimsarticles

Part of the Environmental Sciences Commons, and the Marine Biology Commons

\section{Recommended Citation}

Linker, Lewis C.; Batiuk, Richard A.; Cerco, Carl F.; Shenk, Gary W.; Tian, Richard; Wang, Ping; and Yactayo, Guido, Influence of Reservoir Infill on Coastal Deep Water Hypoxia (2016). Journal of Environmental Quality, 45(3), 887-893. doi: $10.2134 /$ jeq2014.11.0461

This Article is brought to you for free and open access by the Virginia Institute of Marine Science at W\&M ScholarWorks. It has been accepted for inclusion in VIMS Articles by an authorized administrator of W\&M ScholarWorks. For more information, please contact scholarworks@wm.edu. 
Authors

Lewis C. Linker, Richard A. Batiuk, Carl F. Cerco, Gary W. Shenk, Richard Tian, Ping Wang, and Guido Yactayo 


\title{
Influence of Reservoir Infill on Coastal Deep Water Hypoxia
}

\author{
Lewis C. Linker, ${ }^{*}$ Richard A. Batiuk, Carl F. Cerco, Gary W. Shenk, Richard Tian, Ping Wang, and Guido Yactayo
}

\begin{abstract}
Ecological restoration of the Chesapeake through the Chesapeake Bay total maximum daily load (TMDL) requires the reduction of nitrogen, phosphorus, and sediment loads in the Chesapeake watershed because of the tidal water quality impairments and damage to living resources they cause. Within the Chesapeake watershed, the Conowingo Reservoir has been filling in with sediment for almost a century and is now in a state of near-full capacity called dynamic equilibrium. The development of the Chesapeake TMDL in 2010 was with the assumption that the Conowingo Reservoir was still effectively trapping sediment and nutrients. This is now known not to be the case. In a TMDL, pollutant loads beyond the TMDL allocation, which are brought about by growth or other conditions, must be offset. Using the analysis tools of the Chesapeake TMDL for assessing the degree of water quality standard attainment, the estimated nutrient and sediment loads from a simulated dynamic equilibrium infill condition of the Conowingo Reservoir were determined. The influence on Chesapeake water quality by a large storm and scour event of January 1996 on the Susquehanna River was estimated, and the same storm and scour events were also evaluated in the more critical living resource period of June. An analysis was also made on the estimated influence of more moderate high flow events. The infill of the Conowingo reservoir had estimated impairments of water quality, primarily on deep-water and deepchannel dissolved oxygen, because of increased discharge and transport of organic and particulate inorganic nutrients from the Conowingo Reservoir.
\end{abstract}

\section{Core Ideas}

- The Conowingo Reservoir has been filling in with sediment for almost a century.

- It is now in a state of near-full capacity called dynamic equilibrium.

- Conowingo infill causes impairments to Chesapeake water quality.

- The estimated impairments are primarily on deep water dissolved oxygen.

- Increased discharge and transport of nutrients from Conowingo are the cause.

Copyright $\odot$ American Society of Agronomy, Crop Science Society of America, and Soil Science Society of America. 5585 Guilford Rd., Madison, WI 53711 USA.

All rights reserved.

J. Environ. Qual. 45:887-893 (2016)

doi:10.2134/jeq2014.11.0461

This is an open access article distributed under the terms of the CC BY-NC-ND

license (http://creativecommons.org/licenses/by-nc-nd/4.0/)

Received 5 Nov. 2014.

Accepted 27 Jan. 2016

*Corresponding author (LLinker@chesapeakebay.net).
C OASTAL REGIONS worldwide are eutrophic (Nixon, 1995; Kemp et al., 2005; Diaz and Rosenberg, 2008). Coastal watersheds are regions of high population and growth with associated high densities of reservoirs for drinking water, power supply, flood control, and recreation (de Jonge et al., 2002; Paerl, 2006). Reservoirs are filling with sediment and accompanying particulate organic and particulate inorganic nutrients, which are also being retained in their beds (Labadz et al., 1995; Molisani et al., 2006; Morris et al., 2008; Hirsch, 2012; Zhang et al., 2013; Langland, 2015). This study examines the effects of sediment and nutrients from an infilled reservoir on water quality in a downstream eutrophic estuary.

The Chesapeake Bay Program (CBP) is a state-federal partnership engaged in restoring the United States' largest estuary. Chesapeake Bay restoration work has been underway for three decades and since 2010 has been supported by the nation's most extensive total maximum daily load (TMDL) program (USEPA, 2010a; Linker et al., 2013a). The Clean Water Act requires the states of the Chesapeake watershed to establish appropriate uses for their waters, adopt water quality standards that are protective of those uses, and list waterways that are impaired by pollutants, causing them to fail to meet the water quality standards. For waterways on the impaired list, a TMDL must be developed that identifies the maximum amount of pollutants the waterway can receive and still meet water quality standards. Most of Chesapeake Bay and its tidal tributary and embayment waters are impaired because of excess nitrogen, phosphorus, and sediment (USEPA, 2010a). These pollutants enter the water from agricultural operations, urban and suburban stormwater runoff, wastewater facilities, air pollution, septic systems, and other sources. Additional loads brought about by growth or from other causes, such as increased sediment and particulate nutrient loads because of reservoir infill, must be offset to comply with the TMDL.

L.C. Linker, R.A. Batiuk, and G.W. Shenk, US Environmental Protection Agency Chesapeake Bay Program Office, 410 Severn Ave., Suite 109 Annapolis, MD 21403 ; C.F. Cerco, US Army Engineer Research and Development Center, 3909 Halls Ferry Road Vicksburg, MS 39180; R. Tian and G. Yactayo, Univ. of Maryland Center for Environmental Science, Chesapeake Bay Program Office, 410 Severn Ave., Suite 109, Annapolis, MD 21403; P. Wang, Virginia Institute of Marine Science, Chesapeake Bay Office, 410 Severn Ave., Annapolis, MD 21403. Assigned to Associate Editor Peter Kleinman.

Abbreviations: ADH, Adaptive Hydraulics Model; CBP, Chesapeake Bay Program; DO, dissolved oxygen; HSPF, Hydrologic Simulation Program-Fortran; SAV, submerged aquatic vegetation; TMDL, total maximum daily load; WIP, Watershed Implementation Plan; WQSTM, Water Quality and Sediment Transport Model; WSM, Watershed Model Watershed Model (Phase 5.3.2). 
The Susquehanna River basin, sitting at the headwaters of Chesapeake Bay, is the bay's largest watershed and drains an area of $71,200 \mathrm{~km}^{2}$, or $43 \%$ of Chesapeake Bay's total watershed (Fig. 1). The Susquehanna River delivers about $41 \%$ of the nitrogen loads, $25 \%$ of the phosphorus loads, and $27 \%$ of the suspended solids loads to the tidal bay on an annual average basis.

The 2010 Chesapeake Bay TMDL is designed to achieve significant reductions in nitrogen, phosphorus, and sediment pollutant loads throughout the entire $166,000 \mathrm{~km}^{2}$ Chesapeake watershed. The Chesapeake watershed has a population of 17 million people and includes portions of the states of Delaware, Maryland, New York, Pennsylvania, Virginia, and West Virginia and all of the District of Columbia (USEPA, 2010a). The Chesapeake TMDL sets watershed-wide limits of 84.3 million $\mathrm{kg}$ of nitrogen, 5.67 million $\mathrm{kg}$ of phosphorus, and 2.93 billion $\mathrm{kg}$ of sediment per year (USEPA, 2010a). Implementation of the nutrient and sediment limits is through the seven jurisdictions' Watershed Implementation Plans (WIPs), which detail how and when the six Chesapeake Bay watershed states and the District of Columbia will implement management actions sufficient to meet their assigned pollution allocations.

The Conowingo Reservoir is at the outlet of the Susquehanna watershed just prior to the river's discharge to the tidal waters of the Chesapeake (Fig. 1). It has been filling in with sediment and particulate nutrients for almost a century. The 2010 Chesapeake TMDL was based on the assumption that the Conowingo Reservoir was still effectively trapping sediment and nutrient loads, but recent studies indicate that the trapping effectiveness is decreasing (Hirsch, 2012; Zhang et al., 2013; Cerco and Noel, 2016; Langland, 2015). The Conowingo Reservoir is now known to be in a state of near-full capacity, called dynamic equilibrium. The infill of the Conowingo Reservoir results in increased sediment and associated nutrient loads delivered to Chesapeake Bay and estimated water quality impairments on deep-water and deep-channel dissolved oxygen in the tidal Chesapeake.

To examine the estimated influence of Conowingo infill on Chesapeake water quality standards, two approaches were taken. The first was the examination of a model scenario estimating only the effects of additional scour of sediment and particulate nutrients due to reservoir infilling from the bed of Conowingo Reservoir from a particular extreme high flow event $(\sim 17,000$ $\mathrm{m}^{3} \mathrm{~s}^{-1}$ ) in January 1996. The same extreme high flow conditions were also applied in June to estimate the influence of Conowingo scour timing on water quality standards. In the seasonal simulations, the influence of both the loads coming from the watershed and the additional scour due to Conowingo infill were estimated. The second approach was to estimate the influence of increased inputs associated with infilling over a longer time period and

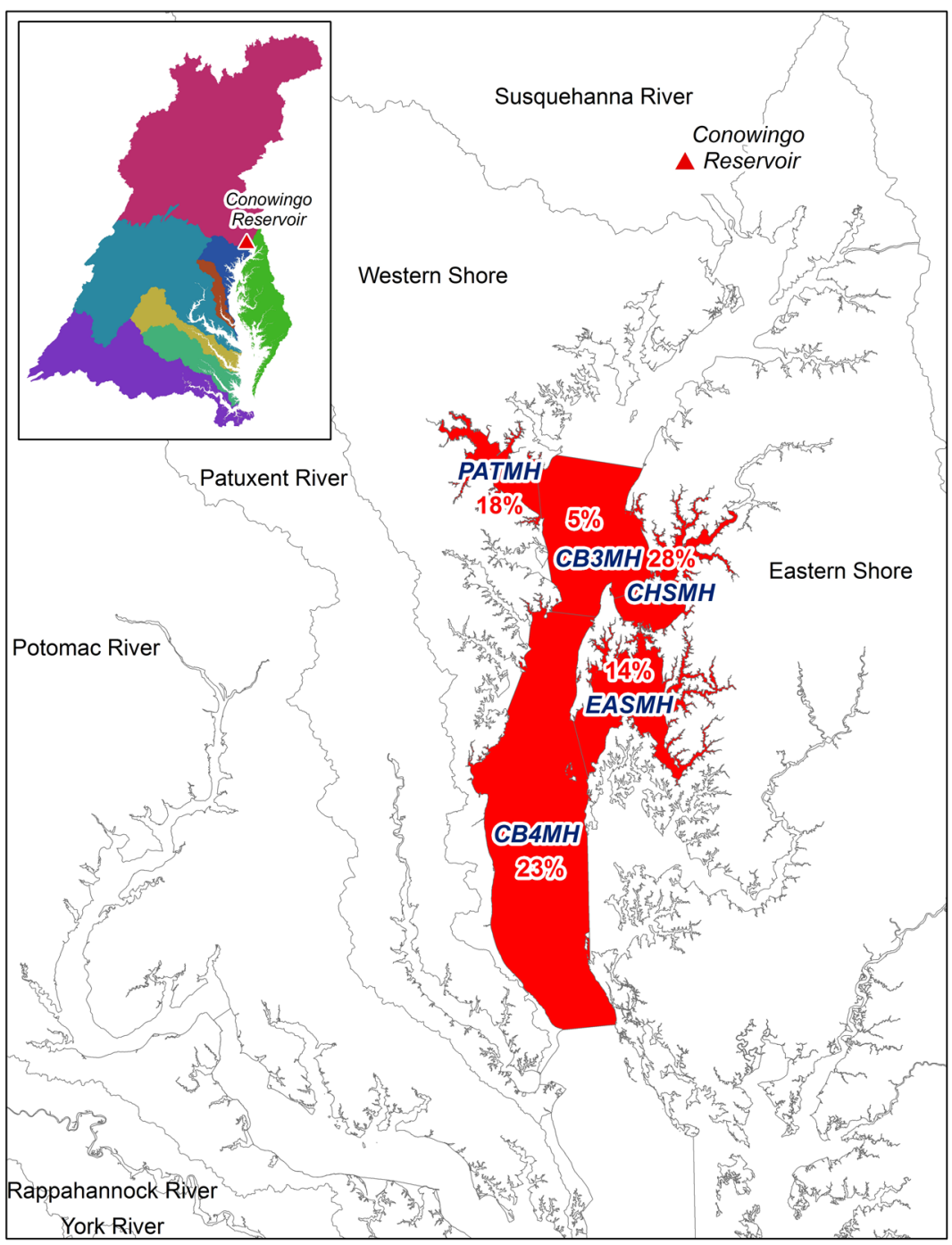

Fig. 1. Chesapeake hypoxia under estimated current conditions represented by deep-channel DO standard nonattainment (see also Table 1, column 3). Insert shows the Chesapeake watershed with the Susquehanna River basin, the location of the Conowingo Reservoir, and other major basins of the Chesapeake watershed. 
broader range of flows, including more moderate high flow events. In particular, effects of estimated increased fluxes in phosphorus and sediment loads by about 55 and $97 \%$ from the Conowingo as reported by Hirsch (2012) were examined.

\section{Materials and Methods}

\section{The Chesapeake Bay Program Modeling System}

Models of the Chesapeake Bay airshed (Community Multiscale Air Quality Model), watershed (Watershed Model [WSM] Phase 5.3.2), and tidal Bay water quality (Water Quality and Sediment Transport Model [WQSTM]) models that were applied to develop the 2010 Chesapeake Bay TMDL allocations (Cerco, 2000; Cerco et al., 2002, 2010; Cerco and Noel, 2004; Linker et al., 2000, 2008; Cerco and Noel, 2013; Linker et al., 2013b; Shenk and Linker, 2013) were also applied to assess the impact of Conowingo Reservoir infill in this study. The Chesapeake WSM, which is based on the Hydrologic Simulation Program-Fortran (HSPF) model, provided the estimated Susquehanna River watershed loads (Shenk and Linker, 2013). The WSM and the Bay WQSTM model were key elements in the assessment of Chesapeake Bay water quality responses (Cerco et al., 2013). For this study, the Adaptive Hydraulics Model (ADH) of the Conowingo Reservoir (Scott and Sharp, 2014) also provided ancillary information for estimated loads of extreme high flow events.

The Bay WQSTM model results were compared with the applicable Chesapeake Bay water quality standards to determine estimated standard compliance. To determine the degree of water quality standard achievement, model scenarios were run representing different Conowingo Reservoir infill management conditions using the WSM and WQSTM models (Linker et al., 2013a; Shenk and Linker, 2013; Cerco et al., 2013). The methods of scenario analysis used in this study were the same used for developing the Chesapeake TMDL nutrient and sediment allocations and are described in Keisman and Shenk (2013).

The tidal Chesapeake has in place ambient water quality criteria protective of five specific Chesapeake Bay tidal water designated uses, along with assessment procedures for dissolved oxygen (DO), water clarity, and chlorophyll a criteria (USEPA, 2003a,b; USEPA, 2010c; Tango and Batiuk, 2013). This paper focuses on the deep-channel DO criteria of DO $\geq 1 \mathrm{mg} \mathrm{L}^{-1}$ from 1 June to 30 September.

\section{Key Hydrologic Periods}

For the Chesapeake TMDL a 3-yr critical period of hydrology, based on key environmental factors-principally rainfall and streamflow-was used as the assessment period of the tidal water quality standards (USEPA, 2010b). The critical period and conditions determined major design conditions of the TMDL (CFR, 2011), in particular, the period of loads, flows, and other environmental conditions when the water quality standards were assessed in the tidal waters.

The 3-yr period selected as the critical period was 1993 to 1995, which was the second-highest flow period of all the eight 3-yr contiguous periods contained in the 1991 to 2000 record (USEPA, 2010c). In Chesapeake Bay, high flows bring high levels of nutrient and sediment loads, resulting in more DO and submerged aquatic vegetation (SAV)-clarity impairments. All scenarios developed for the 2010 TMDL used the 1993 to 1995 critical period (Table 1, columns 2-5).

The highest 3-yr flow and load period contained in the 1991 to 2000 record was 1996 to 1998. In January 1996, the extreme flow event called the Big Melt was brought about by a warming period with rain that fell on snow pack. The January 1996 precipitation over the entire Susquehanna River basin was above average, with the upper portion of the basin receiving precipitation $>75 \%$ above normal. Snowpack over the upper portion

Table 1. Model-estimated level of time and space nonattainment of deep-channel dissolved oxygen (DO) in all Chesapeake Bay segments that have a deep-channel designated use. The first four scenarios (columns 2-5) are key milestone scenarios and are ordered from the highest to the lowest nutrient and sediment loads for the entire Chesapeake watershed. The nutrient and sediment scenario loads are under the scenario title and have units of millions of kilograms for total nitrogen (TN), total phosphorus (TP), and total suspended solids (TSS). The last four columns (columns 6-9) are different Conowingo infill scenarios. Deep-channel variances of $2 \%$ are applied in the central mainstem (CB4MH) and Eastern Bay (EASMH) and $16 \%$ in the lower Chester River (CHSMH). (A variance is an allowable exceedance of an established water quality standard based on the best available data on achievable water quality conditions.) The estimated degree of nonattainment of the deep-channel DO water quality standard is shown in bold type for each deep-water segment of the Chesapeake. Once attainment is estimated to be achieved, the value is shown in italic type.

\begin{tabular}{|c|c|c|c|c|c|c|c|c|}
\hline Scenario & $\begin{array}{c}1985 \\
\text { Scenario } \\
160 \mathrm{TN} \\
11.2 \mathrm{TP} \\
5480 \mathrm{TSS}\end{array}$ & $\begin{array}{c}2010 \\
\text { Scenario } \\
119 \text { TN } \\
8.8 \text { TP } \\
\text { 3790 TSS }\end{array}$ & $\begin{array}{l}\text { TMDL WIP† } \\
\text { Scenario } \\
\text { 87 TN } \\
6.8 \mathrm{TP} \\
\text { 3030 TSS }\end{array}$ & $\begin{array}{l}\text { All Forest } \\
\text { Scenario } \\
24 \mathrm{TN} \\
1.2 \mathrm{TP} \\
610 \mathrm{TSS}\end{array}$ & $\begin{array}{c}\text { Increase of } \\
\text { nonattainment } \\
\text { under Conowingo } \\
\text { scour conditions in } \\
\text { January storm }\end{array}$ & $\begin{array}{c}\text { Increase of } \\
\text { nonattainment } \\
\text { under January } \\
\text { storm conditions } \\
\text { compared with No } \\
\text { Storm Scenario }\end{array}$ & $\begin{array}{c}\text { Increase of } \\
\text { nonattainment } \\
\text { under June } \\
\text { storm conditions } \\
\text { compared with No } \\
\text { Storm Scenario }\end{array}$ & $\begin{array}{c}\text { Increase of } \\
\text { nonattainment } \\
\text { under Moderate } \\
\text { High Flow } \\
\text { conditions }\end{array}$ \\
\hline \multicolumn{9}{|c|}{ CB segment } \\
\hline & & & & & - \% & . & & - \\
\hline CB3MH & 17 & 5 & 0 & 0 & 0 & 1 & 1 & 0 \\
\hline $\mathrm{CB} 4 \mathrm{MH}$ & 49 & 23 & 1 & 0 & 1 & 1 & 4 & 2 \\
\hline CB5MH & 17 & 0 & 0 & 0 & 0 & 0 & 0 & 0 \\
\hline $\mathrm{CHSMH}$ & 39 & 28 & 15 & 0 & 1 & 2 & 8 & 1 \\
\hline EASMH & 29 & 14 & 1 & 0 & 1 & 2 & 3 & 3 \\
\hline PATMH & 42 & 18 & 0 & 0 & 0 & 0 & 0 & 0 \\
\hline РОТМН & 20 & 0 & 0 & 0 & 0 & 0 & 0 & 0 \\
\hline RPPMH & 23 & 0 & 0 & 0 & 0 & 0 & 0 & 0 \\
\hline
\end{tabular}

† Total maximum daily load Watershed Implementation Plan. 
of the basin through 12 January averaged 20 to $25 \mathrm{~cm}$. Mild temperatures in mid-January, combined with rainfall of 1.9 to $3.8 \mathrm{~cm}$, caused extreme high flows from 19 to 24 January that peaked at flows of $\sim 18,000 \mathrm{~m}^{3} \mathrm{~s}^{-1}$ (SRBC 2006). The January 1996 event was used in the extreme high flow scenarios described herein because it is the highest observed and simulated flow $\left(\sim 17,000 \mathrm{~m}^{3} \mathrm{~s}^{-1}\right)$ within the $10 \mathrm{yr}(1991-2000)$ TMDL simulation period of the CBP models. However, the January 1996 event was outside the 1993 to 1995 TMDL critical period, so adjustments to the criteria assessment procedures of the Chesapeake TMDL water quality standards were applied by running the January 1996 extreme flow event with and without scour from the Conowingo Reservoir over the 3-yr period of 1996 to 1998 to isolate the effect of only the scoured sediment and associated particulate nutrients on Chesapeake water quality.

\section{Time and Space Assessment of Standards Attainment}

The degree of achievement of the Chesapeake Bay water quality standards was assessed through quantitative analyses of the WQSTM scenario results for each of the Chesapeake Bay tidal segments. The same methods used for the Chesapeake Bay TMDL were used for the analysis of the Conowingo Reservoir infill scenarios and consisted of an assessment of the percentage of time and space over a 3-yr period (either 1993-1995 or 1996-1998 in this article) that the modeled water quality results exceeded the allowable criterion concentration as described in USEPA (2003a, 2004, 2007, 2008, 2010d) and Keisman and Shenk (2013).

For the Chesapeake TMDL, the water quality standards are assessed by examining the time and space exceedances of the DO criterion above a reference curve based on observations of healthy ecosystem habitats for the assessed criterion (USEPA, 2007; Tango and Batiuk, 2013).

\section{Approach Used to Represent Extreme High Flow Scour of Sediment and Particulate Nutrients from the Conowingo Reservoir}

Conowingo Reservoir scour from the extreme high flow event of January 1996 was represented with the ADH model of the Conowingo using reservoir bathymetries based on surveys of 2011, which represents a full infill, dynamic equilibrium state (Scott and Sharp, 2014). All of the Conowingo assessment scenarios (Table 1, columns 6-9) represent the Conowingo Reservoir as full and in long-term equilibrium between sediment and associated nutrient loads in, and sediment and associated nutrient loads out. The scenario uses estimated sediment and particulate nutrient loads from Conowingo scour as described in Cerco and Noel (2016) based on computations from the ADH model for sediment and from observations from Conowingo sediment cores for particulate nutrients.

\section{Approach Used to Represent Moderate High Flow Event Transport of Sediment and Particulate Nutrients from the Conowingo Reservoir}

Hirsch (2012) examined trends in flow-normalized fluxes of sediment and nutrients at the Conowingo from observations from 1996 to 2011 using a statistical model known as Weighted
Regressions on Time, Discharge, and Season (WRTDS). The findings indicated a $55 \%$ increase in total phosphorus and a $97 \%$ increase in suspended sediment in the flow-normalized flux over the period 1996 to 2011 at Conowingo. The phosphorus and sediment changes represented the changes in the loads from the entire Susquehanna watershed and from changes in reservoir scour and deposition. Nevertheless, the increases of phosphorus and sediment flux from the Conowingo Reservoir occurred despite observed reductions in the fluxes of sediment and phosphorus from an upriver gauge (Marietta, PA) and were attributed to Conowingo infill (Hirsch, 2012; Zhang et al., 2013).

To assess the influence of a broad range of flows including moderate high flow periods under conditions of Conowingo Reservoir infill on Chesapeake Bay water quality, a scenario was developed called the Moderate High Flow Conditions Scenario (Table 1, column 9). Moderate high flow periods were considered to be flows that were greater than about $3000 \mathrm{~m}^{3} \mathrm{~s}^{-1}$ but also included two extreme high flow events in 2011 (Tropical Storm Lee and an unnamed March storm) and the January 1996 event. The scenario approach presents an alternate view of the effects of Conowingo infilling over a broad range of flows rather than a single event.

To represent the Conowingo nutrient and sediment loads estimated by Hirsch (2012), adjustments were made to the parameterization of the Conowingo Reservoir as represented by the WSM. Starting with the 2010 Scenario, the sediment and phosphorus loads resuspended from the Conowingo sediments were increased so that the $10 \mathrm{yr}$ hydrology period (1991-2000) average annual loads at Conowingo were consistent with the Hirsch findings of an increase in total phosphorus loads of about 50\% and an increase in total suspended sediment loads of about $100 \%$ The 2010 Scenario was used to develop the parameterization of the Moderate High Flow Conditions Scenario because it most closely corresponded to the period of flow-normalized flux (1996-2011) used by Hirsch (2012). In the Moderate High Flow Conditions Scenario, the requirement to explicitly simulate the January 1996 Big Melt extreme event was unnecessary, allowing the standard CBP TMDL critical period of 1993 to 1995 to be used.

The HSPF parameters of critical shear stress and erodibility were adjusted to increase simulated sediment loads from the Conowingo Reservoir. The HSPF critical shear stress for bed scour represents the flow threshold at which scour commences. Simulated shear stress above the critical shear stress causes scour to steadily increase in the WSM simulation with higher flows. Also adjusted were the HSPF erodibility coefficients for sand, silt, and clay. The erodibility coefficient for each sediment fraction determines the rate that the fraction is scoured from the bed. The shear stress and erodibility parameters were modified to increase simulated sediment loads from the Conowingo river segment by $100 \%$.

In HSPF, scour of adsorbed nutrients is expressed as the product of the flux of a sediment fraction (sand, silt, or clay) and the concentration of a nutrient, such as phosphate, associated with that sediment fraction. After achieving the desired increase in sediment loads, the next step was to increase the model bed fluxes of phosphate adsorbed to silt and clay to increase the total phosphorus loads from the Conowingo Reservoir discharge by 50\% (Hirsch, 2012) during moderate high flow periods.

The same scour, erodibility, and phosphate bed flux parameters were then modified in the TMDL WIP Scenario until 
the model calculated the same additional amount of sediment and phosphorus as its 2010 Scenario modified counterpart. The Susquehanna sediment and phosphorus loads for the 2010 Scenario were 1040 million and 2.2 million $\mathrm{kg} \mathrm{yr}^{-1}$, respectively. The Susquehanna sediment and phosphorus loads for the 2010 Scenario modified to be consistent with the Hirsch (2012) findings were 2020 million and 3.4 million $\mathrm{kg} \mathrm{yr}^{-1}$, respectively.

\section{Results and Discussion}

\section{Key 2010 TMDL Scenarios Used as a Point of Reference}

Four key scenarios from the 2010 TMDL were used as a point of reference (see Table 1). They include the 1985 Scenario (Table 1, column 2) and 2010 Scenario (column 3), with each applying the simulation conditions of the estimated 1985 or 2010 Chesapeake Bay watershed land use, management actions, populations, point source loads, and atmospheric deposition loads, respectively. The TMDL WIP Scenario (column 4) represents the future conditions when all of the point source, nonpoint source, and atmospheric emission controls in the WIPs are in place to achieve the Chesapeake Bay TMDL in 2025. The All Forest Scenario (column 5) represents the estimated condition of an all forested land use everywhere in the Chesapeake watershed with no point source loads and with conditions of atmospheric deposition loads that would be considered to be pristine (USEPA, 2010a).

The findings for all Chesapeake Bay segments that have a deep-channel DO designated use are shown in Table 1, and the location of the deep-channel segments can be seen in Fig. 1. The first four scenarios in Table 1 are ordered from the highest to the lowest nutrient and sediment loads for key milestone scenarios (columns 2-5). The key milestone scenarios are the 1985 Scenario (160 million kg nitrogen), 2010 Scenario (119 million $\mathrm{kg}$ nitrogen), TMDL WIP Scenario (87 million kg nitrogen), and All Forest Scenario (24 million kg nitrogen). The estimated loads of total phosphorus and total suspended solids are shown as well for each key milestone scenario in millions of kilograms per year. The 1993 to 1995 critical period of hydrology is used, and the deep-channel DO standard has a criterion of at least $1 \mathrm{mg} \mathrm{L}^{-1} \mathrm{DO}$ concentration, which is required to be met at all times.

The estimated degree of nonattainment of the deep-channel DO water quality standard is shown in bold type for each deepwater segment of the Chesapeake. Once attainment is estimated to be achieved, the value is shown in italic type. For example, in the central mainstem Bay (CB4MH, shown in Fig. 1), the estimated degree of deep-channel nonattainment is $49 \%$ of the time and space for the 1985 Scenario, and the degree of nonattainment decreases to an estimated 23\% under the 2010 Scenario, with further decreases until attainment of the water quality standard is estimated to be achieved (with variances as defined in Table 1) under the TMDL WIP Scenario conditions. Additional improvement is estimated under the All Forest Scenario to the point that variances are unnecessary to achieve the water quality standard in the mainstem Bay (CB4MH), lower Chester River (CHSMH), and Eastern Bay (EASMH).

Figure 1 provides a graphical representation of deep-channel DO nonattainment showing the extent of nonattainment under estimated 2010 Scenario (Table 1, column 3) conditions.
The Chesapeake Bay tidal segments of the central mainstem bay $(\mathrm{CH} 3 \mathrm{MH}$ and $\mathrm{CB} 4 \mathrm{MH})$, Eastern Bay (EASMH), Lower Chester River (CHSMH), and Patuxent River (PATMH) are the deepest contiguous waters in the upper Chesapeake. These Chesapeake Bay tidal segments were also the regions estimated to be most sensitive to increases in hypoxia due to Conowingo infill. In contrast to the 2010 Scenario of Fig. 1, under the TMDL WIP Scenario, conditions of full attainment of the deep-channel DO standard are estimated.

\section{Estimating Impact of Extreme High Flow Scour and Transport of Sediment and Particulate Nutrients from the Conowingo Reservoir on Chesapeake Water Quality}

Using the approach described in the "Materials and Methods" section, the TMDL WIP Scenario (Table 1, column 4) was run during the 3-yr period 1996 to 1998 to capture the $1996 \mathrm{Big}$ Melt event with and without the estimated extreme event scour. The difference between these two scenarios is the estimated additional effect of Conowingo extreme high flow scour on the Chesapeake Bay TMDL (Table 1, column 6).

The estimated influence of Conowingo scour loads of particulate nutrients is reported in column 6 of Table 1 (Increase of nonattainment under Conowingo scour conditions in January storm). The estimated response in the deep-channel DO standards was an increase of $1 \%$ nonattainment for $\mathrm{CB} 4 \mathrm{MH}$, EASMH, and CHSMH. The estimated influence of the full 1996 event including the entire Susquehanna watershed storm loads as well as Conowingo scour was an additional $1 \%$ increase in nonattainment in EASMH, CHSMH, and CB3MH (Table 1, column 7).

Dissolved oxygen standards apply to deep-channel and deepwater designated uses. The deep-water region is that volume of the water column below the pycnocline and above the deepchannel designated use. The deep-water DO criterion is a $30-\mathrm{d}$ mean of $3 \mathrm{mg} \mathrm{L}^{-1}$ (USEPA, 2003a). In all respects, the deepwater DO standard response is similar to the response of deepchannel DO. The deep-water results are not shown for brevity but are described in USACE (2015).

The findings of the 2010 Chesapeake Bay TMDL were that deep-channel and deep-water DO water quality standards were difficult to achieve; achievement of these two water quality standards largely drove the magnitude of nutrient pollutant load reductions in setting the 2010 Chesapeake Bay TMDL allocations (USEPA, 2010a). This was also the case with the scenarios of Conowingo Reservoir infill. Deep-channel and deep-water DO were the most sensitive water quality standards to estimated Conowingo Reservoir infill conditions; that is, they were the water quality standards that most readily went into nonattainment with increases in sediment and the associated particulate nutrient loads scoured from the Conowingo Reservoir under estimated infill conditions.

Seasonal scenarios for January and June were also run to illustrate the full impact of an extreme event like the January 1996 Big Melt occurring at different times of the year (Table 1, columns 7 and 8). The June extreme high flow event was developed by moving the January 1996 extreme flows, loads, and scour to June. The January and June seasonal scenarios were each compared with a No-Storm Scenario, in which the January 
extreme event was entirely removed from the simulation record. Therefore, the two seasonal scenarios combine the estimated effects of increased flow, increased loads from the watershed, and increased Conowingo scour from the January 1996 extreme event.

Consistent with the findings of Wang and Linker (2005), a June extreme high flow storm event has the most detrimental influence on deep-channel DO water quality standard attainment. The simulated June extreme flow event (Table 1, column 8) had four times the estimated nonattainment of deep-water DO standards in CB4MH and CHSMH compared with the January extreme flow event (Table 1, column 7) because of the ultimate fate and transport of nutrients in the different seasons. The June extreme event was timed to occur just at the onset of summer hypoxia when the pulse of delivered nutrient loads contributes directly to ongoing summer primary production and resulting hypoxia.

\section{Water Clarity Water Quality Standard Results}

Across all the scenarios described herein, model simulated sediment and associated nutrient loads at the full application of the Chesapeake TMDL WIPs resulted in estimates of full attainment of the SAV-clarity water quality standards in the upper Chesapeake Bay. However, there were estimated detrimental impacts of sediment. For example, light attenuation during the Big Melt extreme event storm moved to the June time period was estimated to have a light attenuation coefficient $\left(K_{\mathrm{e}}\right)$ greater than $2 \mathrm{~m}^{-1}$ for $12 \mathrm{~d}$, a level of light attenuation insufficient for longterm SAV growth and survival. However, light attenuation was estimated to return to sustainable levels after the 12 -d period.

Sediment loads from the Conowingo Reservoir in dynamic equilibrium infill condition are estimated to have little influence on achievement of the Chesapeake Bay SAV-water clarity standards attainment. Additional evidence for the relative insensitivity of Chesapeake water quality conditions to episodic high flow sediment load events is the existence of the large SAV bed in the Chesapeake segment CB1TF (the Susquehanna Flats) which has often exceeded Maryland's SAV-clarity standard for segment CB1TF in recent years (Gurbisz and Kemp, 2014).

\section{Estimating Water Quality Response from Moderate High Flow Transport of Sediment and Particulate Nutrients from the Conowingo Reservoir}

The estimated deep-channel DO water quality attainment under the Moderate High Flow Conditions Scenario compared with the TMDL WIP Scenario, with both using the hydrology period 1993 to 1995 , was an increased nonattainment of $2 \%$ in the segment $\mathrm{CB} 4 \mathrm{MH}, 1 \%$ in the Chester River (CHSMH) segment, and 3\% in the EASMH segment (column 9). The relative nonattainment estimated under the more frequent but moderate high flow conditions is comparable to the level of nonattainment under scenarios of the single extreme flow event.

The mechanisms for the observation of increased sediment and nutrient loads from the Conowingo are unclear and may involve greater transport though the reservoir of sediment and phosphorus loads because of higher turbulence and decreased settling, or greater mobilization though scour, or a combination of these and other mechanisms. The adjustment of HSPF scour applied in this study is silent on the particular mechanisms of the estimated increased sediment and phosphorus loads and is simply an application of an HSPF model method available for empirically representing the Hirsch (2012) load estimates from the Conowingo Reservoir.

\section{Findings and Implications}

The Chesapeake Bay TMDL report projected that there would be future increased nutrient and sediment loads under the conditions of the current dynamic equilibrium state of the Conowingo Reservoir (USEPA, 2010e). In a TMDL, any increase in pollutant loads that results in failure to achieve water quality standards must be addressed and offset so as to ensure full attainment of the applicable water quality standards. The Chesapeake Bay water quality standards most sensitive to increased nutrient loads generally, including the increased nutrient loads estimated under Conowingo infill conditions, are the deep-channel and deep-water DO water quality standards (USEPA, 2010a).

The Conowingo Reservoir was evaluated under the estimated 1996 and 2011 bathymetries with the ADH model to determine the minimum discharge for erosion to commence (Scott and Sharp, 2014). For the 1996 reservoir bathymetry, the minimum discharge for erosion to commence was estimated to be 12,100 $\mathrm{m}^{3} \mathrm{~s}^{-1}$. For the 2011 reservoir bathymetry, the minimum discharge for erosion to commence was estimated to be $9430 \mathrm{~m}^{3} \mathrm{~s}^{-1}$. The scour threshold had been reduced by $22 \%$ between the 1996 and 2011 ADH simulated conditions (S. Scott, personal communication, 2013). As a consequence, more of bottom sediment and associated nutrient loads from the Conowingo Reservoir are estimated to be available for transport to the tidal Chesapeake Bay due to the higher frequency of river flows reaching the lower scour thresholds. The lower scour thresholds as well as decreased particulate deposition could be factors in the findings of Hirsch (2012) as represented in Moderate High Flow Conditions Scenario (Table 1, column 9).

Scoping scenarios provide an estimate of the nitrogen and phosphorus pollutant load reductions from the Susquehanna River watershed needed to offset the increase in DO nonattainment (USEPA, 2010a). To put a 1\% level of nonattainment into context, the nutrient load reduction needed to remove a $1 \%$ level of nonattainment in CB4MH deep-channel DO is equivalent to 1.1 million $\mathrm{kg}$ of additional nitrogen reductions per year or 0.12 million $\mathrm{kg}$ of additional phosphorus reductions per year from the Susquehanna. A load reduction of this magnitude is nontrivial considering the levels of additional management required to achieve those reductions.

The analysis estimated a $1 \%$ increase in deep-channel DO nonattainment in three Chesapeake segments due to extreme flow Conowingo scour alone. The timing of the extreme event is important; a June extreme flow had estimated deep-channel DO nonattainment four times greater than the January extreme flow event. The examination of a broad range of flows, including moderate high flows, provided an estimate of increased deep-channel DO nonattainment of 1 to $3 \%$ in three segments. Ultimately, adaptive management decisions will need to be made to put greater nutrient reductions in place to provide full achievement of water quality standards despite higher nutrient loads from the Conowingo infill condition. 


\section{References}

Cerco, C.F. 2000. Phytoplankton kinetics in the Chesapeake Bay model. Water Qual. Ecosyst. Model. 1:5-49. doi:10.1023/A:1013964231397

Cerco, C.F., B. Johnson, and H. Wang. 2002. Tributary refinements to the Chesapeake Bay model. ERDC TR-02-4. US Army Engineer Corps of Engineers Research and Development Center, Vicksburg, MS

Cerco, C.F., S.C. Kim, and M.R. Noel. 2010. The 2010 Chesapeake Bay eutrophication model. A Report to the US Environmental Protection Agency and to the US Army Corps of Engineer Baltimore District. US Army Engineer Research and Development Center, Vicksburg, MS. http://www. chesapeakebay.net/publications/title/the_2010_chesapeake_bay_eutrophication model1 (accessed 3 March 2012).

Cerco, C.F., and M.R. Noel. 2004. The 2002 Chesapeake Bay eutrophication model. EPA 903-R-04-004. US Environmental Protection Agency, Chesapeake Bay Program Office, Annapolis, MD.

Cerco, C.F. and M.R. Noel, 2013. Twenty-one-year simulation of Chesapeake Bay water quality using the CE-QUAL-ICM eutrophication model. J. Am.Water Resour. Assoc. 40:1119-1133. doi:10.1111/jawr.12107

Cerco, C.F. and M.R. Noel. 2016. Impact of reservoir sediment scour on water quality in a downstream estuary. J. Environ. Qual. doi:10.2134/ jeq2014.10.0425

Cerco, C.F., M.R. Noel, and P. Wang, 2013. The shallow-water component of the Chesapeake Bay environmental model package. J. Am. Water Resour. Assoc. 49:1091-1102. doi:10.1111/jawr.12106

CFR (Code of Federal Regulations), 2011. 40 CFR 130.7: Total maximum daily loads (TMDL) and individual water quality-based effluent limitations. Code of Federal Regulations (annual edition). 50 FR (Federal Register) 1779, Jan. 11, 1985, as amended at 57 FR 33049, July 24, 1992; 65 FR 17170, Mar. 31, 2000; 66 FR 53048, Oct. 18, 2001.

de Jonge, V.N., M. Elliott, and E. Orive. 2002. Causes, historical development, effects and future challenges of a common environmental problem: Eutrophication. Hydrobiologia 475/476:1-19. doi:10.1023/A:1020366418295

Diaz, R.J., and R. Rosenberg. 2008. Spreading dead zones and consequences for marine ecosystems. Science 321(5891):926-929. doi:10.1126/ science. 1156401

Gurbisz, C. and W.M. Kemp, 2014. Unexpected resurgence of a large submersed plant bed in Chesapeake Bay: Analysis of time series data. Limnol. Oceanogr. 59:482-494.

Hirsch, R.M. 2012. Flux of nitrogen, phosphorus, and suspended sediment from the Susquehanna River basin to the Chesapeake Bay during Tropical Storm Lee, September 2011, as an indicator of the effects of reservoir sedimentation on water quality. USGS Scientific Investigations Rep. 1012-5185. USGS, Reston, VA.

Keisman, J. and G. Shenk, 2013. Total maximum daily load criteria assessment using monitoring and modeling data. J. Am. Water Resour. Assoc. 49:1134-1149. doi:10.1111/jawr.12111

Kemp, W. M., W.R. Boynton, J. E. Adolf, D. F. Boesch, W.C. Boicourt, G. Brush, J.C. Cornwell, T.R. Fisher, P.M. Glibert, J. D. Hagy, L.W. Harding, E.D. Houde, D.G. Kimmel, W.D. Miller, R.I.E. Newell, M.R. Roman, E.M. Smith, and J.C. Stevenson. 2005. Eutrophication of Chesapeake Bay: Historical trends and ecological interactions. Mar. Ecol. Prog. Ser. 303:1-29. doi:10.3354/meps303001

Labadz, J.C., D.P. Butcher, A.W.R. Potter, and P. White, 1995. The delivery of sediment in upland reservoir systems. Phys. Chem. Earth 20(2):191-197.

Langland, M.J. 2015, Sediment transport and capacity change in three reservoirs, Lower Susquehanna River Basin, Pennsylvania and Maryland, 1900-2012. US Geological Survey Open-File Rep. 2014-1235. USGS, Reston, VA. doi:10.3133/ofr20141235

Linker, L.C., R.A. Batiuk, G.W. Shenk, and C.F. Cerco, 2013a. Development of the Chesapeake TMDL Allocation. J. Am. Water Resour. Assoc. 49:9861006. doi:10.1111/jawr.12105

Linker, L.C., R. Dennis, G.W. Shenk, R.A. Batiuk, J. Grimm, and P. Wang, 2013b. Computing Atmospheric Nutrient Loads to the Chesapeake Bay Watershed and Tidal Waters. J. Am. Water Resour. Assoc. 49:1025-1041. doi: 10.1111 /jawr.12112

Linker, L.C., G.W. Shenk, R.L. Dennis, and J.S. Sweeney. 2000. Cross-media models of the Chesapeake Bay watershed and airshed. Water Qual. Ecosyst. Model. 1(1-4):91-122. doi:10.1023/A:1013934632305

Linker, L.C., G.W. Shenk, P. Wang, and R. Batiuk. 2008. Integration of modeling, research, and monitoring in the Chesapeake Bay Program. In: J. Albiac and A. Dinar, editors, Management of water quality and irrigation techniques. Earthscan, London. Chapt. 3.

Molisani, M.M., B. Kjerfve, A.P. Silva, and L.D. Lacerda. 2006. Water discharge and sediment load to Sepetiba Bay from an anthropogenically-altered drainage basin, SE Brazil. J. Hydrol. 331(3-4):425-433.
Morris, G., G. Annandale, and R. Hotchkiss. 2008. Reservoir sedimentation. In: M. Garcia, editor, Sedimentation engineering: Processes, measurements, modeling, and practice. American Society of Civil Engineers, Reston, VA. p. 579-612. doi:10.1061/9780784408148.ch12

Nixon, S.W. 1995. Coastal marine eutrophication: A definition, social causes, and future concerns Ophelia 41(1):199-219.

Paerl, H.W. 2006. Assessing and managing nutrient-enhanced eutrophication in estuarine and coastal waters: Interactive effects of human and climatic perturbations Ecol. Eng. 26(1):40-54.

Scott, S.H., and J.A. Sharp. 2014. Sediment transport characteristics of Conowingo Reservoir: Appendix B to Lower Susquehanna River watershed assessment, Maryland and Pennsylvania. US Army Corps of Engineers, Baltimore, MD

Shenk, G.W. and L.C. Linker, 2013. Development and application of the 2010 Chesapeake watershed total maximum daily load model. J. Am. Water Resour. Assoc. 49:1042-1056. doi:10.1111/jawr.12109

SRBC. 2006. January 1996 flash flood in the Susquehanna River. Susquehanna River Basin Commission. http://www.srbc.net/programs/flood96.htm (accessed 23 Feb. 2016).

Tango, P.J. and R.A. Batiuk, 2013. Deriving Chesapeake Bay water quality standards. J. Am. Water Resour. Assoc. 49:1007-1024.

USACE. 2015. Lower Susquehanna River watershed assessment report. US Army Corps of Engineers, Baltimore District, Baltimore, MD.

USEPA. 2003a. Ambient water quality criteria for dissolved oxygen, water clarity, and chlorophyll a for the Chesapeake Bay and its tidal tributaries. EPA 903-R-03-002. US Environmental Protection Agency, Region 3, Chesapeake Bay Program Office, Annapolis, MD.

USEPA. 2003b. Technical support document for identification of Chesapeake Bay designated uses and attainability. EPA 903-R-03-004. US Environmental Protection Agency, Region 3, Chesapeake Bay Program Office, Annapolis, MD.

USEPA. 2004. Ambient water quality criteria for dissolved oxygen, water clarity, and chlorophyll a for the Chesapeake Bay and its tidal tributaries: 2004 addendum. EPA 903-R-03-002. US Environmental Protection Agency, Region 3, Chesapeake Bay Program Office, Annapolis, MD.

USEPA. 2007. Ambient water quality criteria for dissolved oxygen, water clarity, and chlorophyll a for the Chesapeake Bay and its tidal tributaries: 2007 addendum. EPA 903-R-07-003. CBP/TRS 285-07. US Environmental Protection Agency, Region 3, Chesapeake Bay Program Office, Annapolis, MD.

USEPA. 2008. Ambient water quality criteria for dissolved oxygen, water clarity, and chlorophyll a for the Chesapeake Bay and its tidal tributaries: 2008 technical support for criteria assessment protocols addendum. EPA 903-R08-001. CBP/TRS 290-08. US Environmental Protection Agency, Region 3, Chesapeake Bay Program Office, Annapolis, MD.

USEPA. 2010a. Chesapeake Bay total maximum daily load for nitrogen, phosphorus, and sediment. US Environmental Protection Agency Chesapeake Bay Program Office, Annapolis MD.

USEPA. 2010b. Chesapeake Bay total maximum daily load for nitrogen, phosphorus, and sediment: Appendix F. Determination of the hydrologic period for model application. US Environmental Protection Agency Chesapeake Bay Program Office, Annapolis MD. http://www.epa.gov/reg3wapd/tmdl/ChesapeakeBay/tmdlexec.html (accessed 2 Feb. 2012).

USEPA. 2010c. Chesapeake Bay total maximum daily load for nitrogen, phosphorus, and sediment: Appendix G. Determination of critical conditions for the Chesapeake Bay TMDL. US Environmental Protection Agency Chesapeake Bay Program Office, Annapolis MD. < http://www.epa.gov/ reg3wapd/tmdl/ChesapeakeBay/tmdlexec.html (accessed 2 Feb. 2012).

USEPA. 2010d. Ambient water quality criteria for dissolved oxygen, water clarity, and chlorophyll a for the Chesapeake Bay and its tidal tributaries: 2010 technical support for criteria assessment protocols addendum. May 2010. EPA 903-R-10-002. CBP/TRS 301-10. US Environmental Protection Agency, Region 3 Chesapeake Bay Program Office, Annapolis, MD.

USEPA. 2010e. Chesapeake Bay total maximum daily load for nitrogen, phosphorus, and sediment: Appendix T. Sediments behind the Susquehanna dams technical documentation-Assessment of the Susquehanna River reservoir trapping capacity and the potential effect on the Chesapeake Bay. US Environmental Protection Agency Chesapeake Bay Program Office, Annapolis MD. http://www.epa.gov/reg3wapd/tmdl/ChesapeakeBay/ tmdlexec.html (accessed 2 Feb. 2012).

Wang, P., and L.C. Linker. 2005. Effect of timing of extreme storms on Chesapeake Bay submerged aquatic vegetation. In: K.G. Sellner editor, Hurricane Isabel in perspective. CRC Publ. 05-160, Chesapeake Research Consortium, Edgewater, MD, p. 177-185. http://www.chesapeake.org/pubs/ Isabel/Wang\%20and\%20Linker.pdf (accessed August 2012).

Zhang, Q., D.C. Brady, and W.P. Ball. 2013. Long-term seasonal trends of nitrogen, phosphorus, and suspended sediment load from the non-tidal Susquehanna River Basin to Chesapeake Bay. Sci. Total Environ. 452-453:208221. doi: $10.1016 /$ j.scitotenv.2013.02.012 